\title{
Filling the gap: Using fishers' knowledge to map the extent and intensity of fishing activity
}

Szostek, Claire; Kaiser, Michel; Murray, Lee; Bell, Ewen

\section{Marine Environmental Research}

Published: 20/06/2017

Version created as part of publication process; publisher's layout; not normally made publicly available

Cyswllt i'r cyhoeddiad / Link to publication

Dyfyniad o'r fersiwn a gyhoeddwyd / Citation for published version (APA):

Szostek, C., Kaiser, M., Murray, L., \& Bell, E. (2017). Filling the gap: Using fishers' knowledge to map the extent and intensity of fishing activity. Marine Environmental Research.

\footnotetext{
Hawliau Cyffredinol / General rights

Copyright and moral rights for the publications made accessible in the public portal are retained by the authors and/or other copyright owners and it is a condition of accessing publications that users recognise and abide by the legal requirements associated with these rights.

- Users may download and print one copy of any publication from the public portal for the purpose of private study or research.

- You may not further distribute the material or use it for any profit-making activity or commercial gain

- You may freely distribute the URL identifying the publication in the public portal ?
}

Take down policy

If you believe that this document breaches copyright please contact us providing details, and we will remove access to the work immediately and investigate your claim. 


\section{Accepted Manuscript}

Filling the gap: Using fishers' knowledge to map the extent and intensity of fishing activity

Claire L. Szostek, Lee G. Murray, Ewen Bell, Michel J. Kaiser

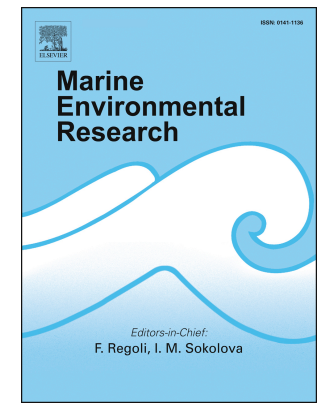

PII:

S0141-1136(17)30119-8

DOI:

10.1016/j.marenvres.2017.06.012

Reference: MERE 4326

To appear in: Marine Environmental Research

Received Date: 27 February 2017

Revised Date: 25 May 2017

Accepted Date: 19 June 2017

Please cite this article as: Szostek, C.L., Murray, L.G., Bell, E., Kaiser, M.J., Filling the gap: Using fishers' knowledge to map the extent and intensity of fishing activity, Marine Environmental Research (2017), doi: 10.1016/j.marenvres.2017.06.012.

This is a PDF file of an unedited manuscript that has been accepted for publication. As a service to our customers we are providing this early version of the manuscript. The manuscript will undergo copyediting, typesetting, and review of the resulting proof before it is published in its final form. Please note that during the production process errors may be discovered which could affect the content, and all legal disclaimers that apply to the journal pertain. 
1 Filling the gap: Using fishers' knowledge to map the extent and intensity of fishing activity.

\section{Claire L. Szostek1, Lee G. Murray1, Ewen Bell2 and Michel J. Kaiser1}

1School of Ocean Sciences, Bangor University, Menai Bridge, Anglesey LL59 5AB, UK

${ }_{2}$ Cefas, Pakefield Road, Lowestoft, Suffolk NR33 0HT, UK

*Corresponding author: tel: +44 1248 383751; fax: +44 1248 716367; e-mail c.szostek@bangor.ac.uk

\section{Abstract}

Knowledge of the extent and intensity of fishing activities is critical to inform management in relation to fishing impacts on marine conservation features. Such information can also provide insight into the potential socio-economic impacts of closures (or other restrictions) of fishing grounds that could occur through the future designation of Marine Conservation Zones (MCZs). We assessed the accuracy and validity of fishing effort data (spatial extent and relative effort) obtained from Fishers' Local Knowledge (LK) data compared to that derived from Vessel Monitoring System (VMS) data for a high-value shellfish fishery, the king scallop (Pecten maximus L.) dredge fishery in the English Channel. The spatial distribution of fishing effort from LK significantly correlated with VMS data and the correlation increased with increasing grid cell resolution. Using a larger grid cell size for data aggregation increases the estimation of the total area of seabed impacted by the fishery. In the absence of historical VMS data for vessels $\leq 15 \mathrm{~m}$ LOA (Length Overall), LK data for the inshore fleet provided important insights into the relative effort of the inshore $(<6 \mathrm{NM}$ from land) king scallop fishing fleet in the English Channel. The LK data provided a good representation of the spatial extent of inshore fishing activity, whereas representation of the offshore fishery was more precautionary in terms of defining total impact. Significantly, the data highlighted frequently fished areas of particular importance to the inshore fleet. In the absence of independent sources of geospatial information, the use of LK can inform the development of marine planning in relation to both sustainable fishing and conservation objectives, and has application in both developed and developing countries where VMS technology is not utilised in fisheries management. 
Mapping temporal and spatial patterns of fishing activity is an integral part of marine spatial planning. This includes determining the spatial extent of the environmental impacts of fishing (Jennings \& Lee, 2012) and the potential economic impacts of proposed management measures used to control fishing activities (Pederson et al., 2009). Data for specific gears, at a relevant spatial scale is required in order to understand conflicting pressures on marine ecosystems (Campbell et al. 2014). In the absence of systems that gather fisheries management data, information can be gathered directly from fishers (Bergmann et al., 2004; Drew, 2005; Hall \& Close, 2007; Shepperson et al., 2014). Previously, scientists have utilised Local Knowledge (LK) from fishers to: ascertain where fishing occurs; understand the seasonality of fishing; identify locations of potential gear conflict; place economic or perceived value on fishing grounds; aid the design and planning of Marine Protected Areas (MPAs); attain estimates of fishing intensity (Close \& Hall, 2006; Lieberknecht et al., 2011; Yates \& Schoeman, 2013; Leite et al., 2013). Fishers can have a greater ability to detect short-term trends in fisheries than the available scientific data and are able to provide information on year-to-year variability in fish stocks (Rochet et al., 2008). Scientific surveys are often limited in temporal and spatial scales. However, experienced fishers interact with the fishery environment on a daily basis and can have years of knowledge and experience that can supplement modern data collection.

Nevertheless, there are limitations associated with spatial data gathered from fishers. For example, LK is not as precise as that obtained from vessel monitoring systems which can reveal the exact location of fishing activities (Shepperson et al., 2014), and can be used to determine fishing tracks. However, LK data can provide a reasonable estimation of the spatial extent of fishing; verified by comparing maps of fishing effort derived from LK data to 100 $\%$ VMS coverage for a fleet (Shepperson et al., 2014). Aggregation of data at a finer scale provides a more accurate representation of the spatial extent of the fishery. However, when using LK to estimate fishing intensity the accuracy increases with the proportion of the fleet sampled and aggregation of the data at a coarser scale (Shepperson et al., 2014). In some cases fisher knowledge represents the best, or only, available data. In the UK, the value of LK to inform the spatial management of inshore fisheries is recognised. Comparable projects to ascertain spatial patterns of fishing activity and the economic value of fishing grounds have been undertaken in Scotland (Kafas et al., 2014), Ireland (Yates \& Shoeman, 2013), England 
(Turner et al., 2015) and North Wales ('Fish Map Môn' project, des Clers et al., 2008). In

64

65

66

67

68

69

particular, data from the ScotMap project has been useful in marine spatial planning in areas where multiple uses such as renewable energy and conservation features co-occur (Kafas et al., 2014).

\section{Mapping fishing activity}

VMS data are gathered primarily for fisheries management and enforcement purposes, and the data are frequently used to analyse spatial fishing patterns and estimate fishing effort (e.g. Mills et al., 2007; Hintzen et al., 2010; Lee \& Jennings, 2010; Gerritsen et al., 2013). In the European Union, VMS has been compulsory for all commercial fishing vessels $>15 \mathrm{~m}$ LOA since 2005 and for vessels $>12 \mathrm{~m}$ LOA since 2012. However, $>90 \%$ of registered fishing vessels in England and Wales are $\leq 15$ m LOA (MMO, 2012), which means that there is a lack of spatial effort data for this sector of the fleet.

Scallop vessel fleets are often defined into two categories; 'inshore', and 'offshore' (Palmer, 2006; Howarth \& Stewart 2014). The UK offshore fleet, comprises vessels that are typically $>15 \mathrm{~m}$ LOA (vessels of this size are not permitted to fish within $6 \mathrm{NM}$ of the coast) and the inshore fleet (vessels typically $<15 \mathrm{~m} \mathrm{LOA}$ ) that operate closer to shore. There is no VMS coverage for the majority of the inshore fleet, of which $c .50 \%$ are $<12 \mathrm{~m} \mathrm{LOA}$. In the absence of VMS data, other methods have been employed to describe the location and intensity of inshore fishing activity, such as combining environmental data with expert information on the location of fishing to estimate the area of sea impacted (Dunn et al., 2010). Breen et al. (2014) used records of observed fishing activity from fisheries enforcement data to calculate sightings-per-unit-effort (SPUE) as a measure of relative fishing intensity. In the latter study, although correlation with VMS data (where this was available) was high, limitations included a low density of sightings data, compromised positional accuracy in some areas, the sporadic nature of data collection and gaps in the data set for areas not visited by fisheries enforcement vessels.

In the present study we use a UK king scallop fishery as a case study due to its high economic value and spatial footprint. The physical impact of scallop dredging varies with seabed habitat, ranging from severe (Kaiser et al., 2006) to that indistinguishable to impacts from natural disturbance (Sciberras et al., 2013). In the UK scallop landings support the third most valuable fishery. However, at present, the lack of VMS data for the inshore scallop 
sector impedes our ability to understand the wider ecosystem effects of these fishing activities. Due to commitments under the EU Habitats Directive (92/43/EEC, Council of the European Union, 1992) and the Marine Strategy Framework Directive (MSFD, 2008/56/EC, Council of the European Union, 2008) to develop networks of Marine Protected Areas (MPAs), coupled with the number of livelihoods reliant on inshore fisheries in the UK (Breen et al., 2014), understanding the spatial distribution and intensity of inshore fishing activity is essential for marine spatial planning and the assessment of the compatibility of fishing activities with conservation features. There is currently no available resource that provides comprehensive coverage of inshore scallop fishing activity due to a lack of VMS data for this sector. The aim of the present study was to understand whether it was possible to fill data gaps (in a reliable manner) in relation to the spatial distribution and intensity of scallop dredging using the English Channel as a case study, by gathering LK from scallop fishermen that have been active during the last decade. The following objectives were addressed:

1. Map the spatial extent and relative intensity of inshore ( $\leq 15 \mathrm{~m} \mathrm{LOA}$ vessels) and offshore (>15 m LOA vessels) king scallop (Pecten maximus L.) fishing activity in the English Channel.

2. Assess the validity of using fishers' LK to estimate the extent and relative intensity of scallop dredging by comparing maps of LK with VMS data (for vessels >15 m LOA).

\section{Methods}

Data for all UK vessels that landed king scallops from the English Channel (ICES sub-areas VIId and VIIe) in the eight years prior to this study were obtained from the Marine Management Organisation (MMO). The mean number of vessels that exploited the king scallop fishery annually in ICES sub-areas VIId and VIIe, between 2006 and 2013, was 155 (Table 1).

Table 1: Total number of vessels targeting king scallops \pm S.E. (includes data from trips by vessels where king scallops were the main retained species, or king scallop dredges were used) caught in ICES sub-areas VIId and VIIe, split by vessel length.

\begin{tabular}{cccc}
\hline Year & $\leq \mathbf{1 5}$ m LOA vessels & $>$ 15 $\mathbf{~}$ LOA vessels & Total vessels \\
\hline $\mathbf{2 0 0 6}$ & 96 & 37 & 133 \\
$\mathbf{2 0 0 7}$ & 111 & 31 & 142 \\
$\mathbf{2 0 0 8}$ & 127 & 23 & 150 \\
$\mathbf{2 0 0 9}$ & 125 & 28 & 153
\end{tabular}




\begin{tabular}{llll}
$\mathbf{2 0 1 0}$ & 102 & 35 & 137 \\
$\mathbf{2 0 1 1}$ & 132 & 41 & 173 \\
$\mathbf{2 0 1 2}$ & 131 & 36 & 167 \\
$\mathbf{2 0 1 3}$ & 142 & 39 & 181 \\
\hline
\end{tabular}

$\begin{array}{llll}\text { mean 2006-2013 } & 121( \pm 5.7) & 34( \pm 2.1) & 155( \pm 6.2)\end{array}$

122 A semi-structured questionnaire (appendix 1) was administered to scallop fishermen who

123 were contacted via the UK Scallop Association, the South-West Fish Producers Organisation

124 (SWFPO) and referrals provided by fishermen. All of the participants were full-time skippers

125 of vessels that targeted king scallops for all or part of the year. The first section of the

126 questionnaire involved a series of 39 quantitative and qualitative questions regarding vessel

127 and gear characteristics, fishing habits, economics and opinions regarding the management of

128 the fishery. Questions were either: closed; required an answer based on a Likert scale (Likert,

129 1932); or were structured in an open format to encourage greater sharing of information. The

130 fishermen were not provided the questionnaire prior to the interview, as it was hoped that

131 obtaining spontaneous answers to the questions would avoid bias. Much of the information

132 given during the interviews was anecdotal and therefore not reported in the present study, in

133 which we focus on the spatial distribution of fishing effort.

134 The mapping exercise involved fishermen identifying all locations in the English Channel 135 where they had actively fished for king scallops with their current vessel, over the 10 year 136 period prior to the date of the interview. This time period was used, as this was the maximum 137 time period the authors expected to obtain reliable data, due to the information being reliant 138 on the memory of the skipper on the day of the interview. All interviews were conducted in 139 person, by the lead author (CLS), between March 2012 and March 2013, therefore the 140 response periods range from March 2002-2012 to March 2003-2013. Fishing locations were 141 identified either by drawing polygons directly onto a geo-referenced admiralty chart of the

142 English Channel in ArcMap v.9.1, using software developed for the 'FisherMap' project (des

143 Clers et al., 2008), or by drawing directly onto an A3 sized printed admiralty chart. Some 144 skippers had worked on the same vessel for the full 10 year period, while others had recently 145 changed vessels, or were more recently qualified as skippers. Data for fishing locations was 146 only recorded for the time period the interviewee had been the skipper of the vessel. This was 147 to avoid any duplication of data if more than one fisher had skippered a particular vessel, 148 which occurred a number of times. For each polygon drawn, participants were asked to 149 indicate which months in the year they normally visited the location to fish, and on average 150 how many days per month fishing activity occurred. They were also asked to indicate how 
many years in the last 10 (or as long as they had been skipper of the vessel, if <10 years) they had returned to fish within the specified polygon. Interviews were conducted with 19 skippers of vessels $>15 \mathrm{~m}$ LOA (length overall) and 29 skippers of vessels $\leq 15 \mathrm{~m}$ LOA between summer 2012 and autumn 2013. Based on data provided by the MMO for scallop vessel activity in recent years (Table 1) this constituted approximately $54 \%$ and $25 \%$ respectively of the mean number of full and part-time scallop vessels operating in ICES sub-areas VIId and VIIe over the past decade. Full-time scallop vessels are defined as those that use only scallop gear throughout the year. Part-time scallop vessels are those that target scallops during certain times of the year but target other species with different gear (e.g. beam-trawl)

160 the remainder of the year. There were more frequent opportunities to interview skippers of 161 vessels $\leq 15 \mathrm{~m} \mathrm{LOA}$, as vessels of this size tend to return to port each day and are less able to 162 fish in high wind conditions. There were fewer opportunities to interview skippers of larger 163 vessels as they spend up to a week at sea per trip and after landing the catch often leave port 164 immediately for the next fishing trip. There are 19 landing ports along the south coast of 165 England (Figure 1). Interviews were conducted with skippers of vessels either registered at, 166 or landing into 13 of these ports, to provide a representative spread of samples across the 167 study area. This included English, Scottish and, to a lesser extent, Welsh owned vessels.




169 Figure 1: The location of English ports along the English Channel where king scallops are landed.

170 Red stars indicate the home ports or landing ports of scallop fishermen that were interviewed. No scallop fishermen were interviewed from ports indicated by black triangles. The boundaries of ICES sub-areas VIId and VIIe are shown with dashed lines. Data provided by the Marine Management

173 Organisation.

\section{Data Analysis}

\section{Vessel characteristics}

176 For the purposes of analysis, where skippers were unable, or chose not to provide an answer

177 to a question, missing data was dealt with by entering the average response for vessels with 178 similar characteristics. First, a Draftsman's plot was performed in PRIMER-E (Clarke \& 179 Gorley, 2006) to test for significant autocorrelation between the variables: total number of 180 dredges; maximum hours fishing per day; total days fishing activity in last 12 months; 181 minimum tow duration; maximum tow duration; minimum tow speed; maximum tow speed; 182 minimum mean catch weight (king scallops) per day; maximum mean catch weight (king 183 scallops) per day; minimum trip length (days); maximum trip length (days); maximum wind 184 force fished; \% grounds visited in last 12 months that have been fished previously; maximum 185 distance travelled to fish; increase in distance travelled in last 10 years; vessel length; engine power; number of crew; minimum crew; maximum crew. To test the hypothesis that vessel characteristics and fishing behaviour differ between fleet sectors (dictated by vessel size), a multivariate analysis of vessel characteristics was performed using PRIMER-E. The data were normalised and a resemblance matrix of the similarity between vessels was created using Euclidean distance as the measure of the similarity. An ANOSIM test was used to ascertain whether characteristics were significantly different between vessels grouped by

192 LOA $(\leq 15 \mathrm{~m} ;>15 \mathrm{~m})$. The SIMPER function was used to ascertain the percentage similarity of characteristics within group and percentage dissimilarity between groups.

\section{LK Fishing polygons}

195 Fishing activity recorded during fisher interviews was weighted according to the frequency of use indicated by the interviewee, then aggregated by polygon to give an estimation of the relative fishing effort exerted across all fishing grounds over the total time period. The number of fishing days per year (days $\mathrm{yr}^{-1}$ ) was calculated for each polygon by summing the number of days the area was visited over each 12 month period. To provide a relative value of fishing effort over the full 10 year period covered by the interview, a weighting (0-1) was then applied. For example, if a skipper had fished in a polygon area once in the previous 10 
years, a weighting of 0.1 was applied to the total days per year; whereas if the area had been

203 fished biennially (5/10 years), a weighting of 0.5 was applied. This enabled integration of data from all interviews, which covered varying time periods, to provide a measure of relative fishing intensity. Then all polygons were joined using the 'Union' tool, to produce a map of relative fishing effort over the 10 year period. Polygons for $>15 \mathrm{~m} \mathrm{LOA}$ and $\leq 15 \mathrm{~m}$ vessels were treated separately.

208 For each of the two length groups of vessels, fishing polygons were converted to a continuous raster layer using the mean of all values within a cell and the cell centre assignment method, with an output cell size of 0.025 decimal degrees (approximately $1.8 \times 2.8 \mathrm{~km}$ at $50^{\circ} \mathrm{N}$ ), as this was the scale at which the VMS data was aggregated (see below). If a skipper of an >15 $\mathrm{m}$ LOA vessel had drawn a polygon on the map that fell inside the 6 NM zone (0-6 NM from the shore) it was assumed to be a result of the coarse method of recording, rather than an intentional indication of fishing effort. To eliminate this error, the raster layer for the $>15 \mathrm{~m}$ vessels was converted to a point grid layer of $0.025^{\circ}$. Points that fell inside of this zone were removed and the resultant point data were then converted back to a raster of cell size of $0.025^{\circ}$ using a mean cell assignment type.

\section{Comparison of VMS and LK data}

To validate the accuracy of LK for the $>15 \mathrm{~m}$ vessels, the data were compared with the VMS data. The VMS data represent total fishing activity for the period (for vessels $>15 \mathrm{~m} \mathrm{LOA}$ ), whereas the LK data were gathered from a sample of the fleet and therefore represent relative fishing effort. Our aim in this study is to highlight the distribution of effort in recent years, and the total spatial extent of fishing effort, therefore the discrepancy in the total time periods covered by the two datasets will not adversely impact the findings. Vessels $>15 \mathrm{~m}$ LOA are not permitted to fish within $6 \mathrm{NM}$ of the coastline in the English Channel therefore a $6 \mathrm{NM}$ buffer was applied to the VMS data and only records outside of this zone were retained for the comparison of VMS with LK. Data from ICES sub-areas VIId, e and h (outside of the 6 NM mile zone) were included, as fisher polygons included fishing effort in all of these areas. Anonymised VMS point data (aggregated at a scale of $0.025^{\circ}$ ) for all UK and foreign scallop vessels, for the period 2005-2013 inclusive, were obtained. This time period was used as this was the data available in aggregated, anonymised format from the MMO, thereby fulfilling

232 data confidentiality requirements. Scallop vessels are engaged in fishing activity at speeds of $233>2$ knots (nautical miles per hour) and <3.5 knots (Lee et al., 2010; Lambert et al., 2012), 
therefore the dataset was filtered to include only records that fell within these margins. The sum of the time interval (total hours) between VMS transmissions was used as a measure of fishing effort over the time period and the point data were converted to a continuous raster in ArcMap v.10, using $0.025^{\circ}$ grid cells. The VMS data were also aggregated using the 'Aggregate' tool, into grid cells of 0.1 and 0.3 decimal degrees (using the mean value) for comparison with the LK data.

240 The size of grid cell used for the aggregation of VMS data can over- or under-estimate the spatial extent and intensity of fishing activity (Piet and Quirjins, 2009; Gerritsen et al., 2013). Therefore, vector analysis grids of differing cell sizes $(0.1 ; 0.2 ; 0.25$ and 0.3 decimal degrees $)$ were created using the 'Create Fishnet' tool in ArcMap in order to visually assess the suitability of different scales. Due to the trade-off between resolution and accuracy and the distortion that occurs at the boundaries of the polygons, $0.3^{\circ}$ grid cells were the largest size of cell used for aggregation. The 'Zonal Statistics as Table' tool was used to obtain mean VMS and LK fishing effort values for each fishnet polygon, at each spatial scale. The resultant tables for VMS and LK data were joined and the data points for each corresponding polygon plotted against each other. Correlations were tested for significance using a generalised linear modelling approach in R (R Development Core Team, 2008) and models were evaluated by checking for homogeneity of residuals. Visual assessment of frequency histograms of intensity values indicated that the data distribution was skewed towards low activity values. Aggregated relative fishing intensity data at each resolution were displayed on maps in seven breaks using the Jenks natural breaks classification (Jenks, 1967). This maximises the variation between groups in order to optimise visualisation of the relative spatial distribution of fishing activity. The maps representing aggregated raw LK data were sent to scallop fishermen that had taken part in the industry questionnaires, for visual validation.

\section{$258 \quad$ Results}

\section{Vessel characteristics}

260 A draftsman plot was used to investigate significant auto-correlation between vessel 261 characteristics. Engine power and vessel LOA were significantly correlated $(\rho>0.95)$ with the total number of dredges, therefore only the latter parameter (no. of dredges) was retained in the multivariate analysis (Clarke \& Warwick, 2001). An MDS plot (2D stress=0.06; Figure 2) and accompanying ANOSIM test of normalised vessel characteristics indicated that vessels 
of different size (LOA of $\leq 15$ and $>15 \mathrm{~m}$ ) displayed significantly different physical characteristics and fishing behaviours (ANOSIM: $\mathrm{R}=0.692, \mathrm{p}=0.001$ ). A summary of mean vessel characteristics, by group is given in appendix 2. SIMPER revealed high within group similarity for $\leq 15 \mathrm{~m}$ and $>15 \mathrm{~m}$ LOA vessels (82.9 and $92.1 \%$ respectively), and average dissimilarity between groups of $29 \%$. Hence, in further analysis and the discussion we continue to refer to two groups of vessels; 'inshore' $(\leq 15 \mathrm{~m} \mathrm{LOA})$ and 'offshore' $(>15 \mathrm{~m}$ 271 LOA) vessels.

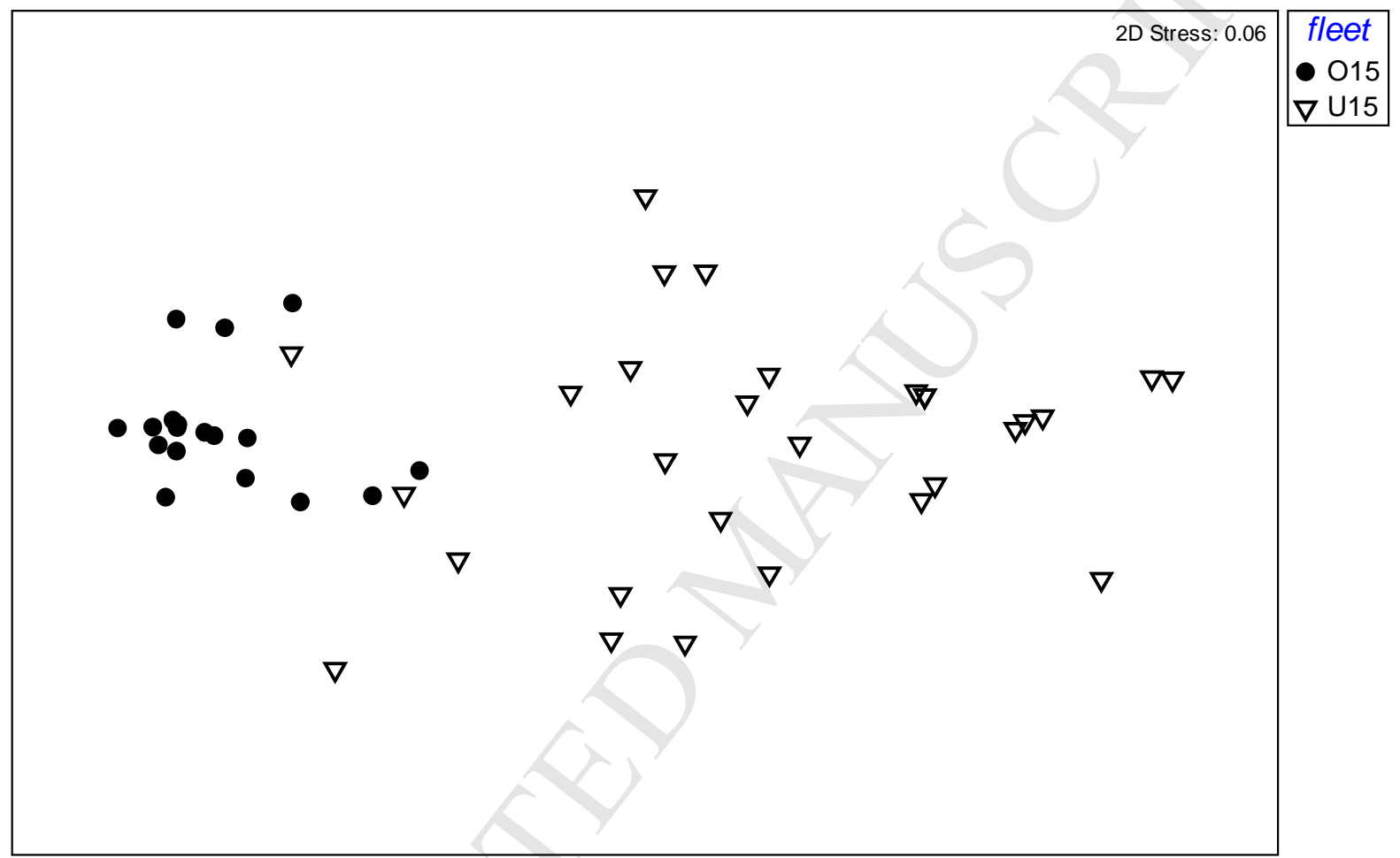

Figure 2: A multi-dimensional scaling plot of scores assigned to scallop vessel characteristics. Data was normalised prior to creating the resemblance matrix. Vessel characteristics included in the analysis are listed in the methods section. Symbols represent vessel LOA (solid circle >15m LOA;

When plotting the fishing effort data, the estimate of the total area of extent impacted increased with the grid cell size used for data aggregation. This effect was most pronounced

281 for the VMS data, due to the high resolution of the original data set (Table 2). There was a marked increase in area of extent impacted for the offshore LK data when the grid cell was increased from 0.1 to 0.3 decimal degrees. In contrast, there was a slight decrease in the overall area of extent impacted for the inshore LK data when the grid cell was increased from 0.1 to 0.2 (Table 2). 
286 As the grid cell size increased there was an increase in the correlation between relative

287 fishing effort estimated from aggregated VMS and offshore LK data (Figure 3), however all

288 correlations were significant (Table 3). As grid cell size increased so did the spatial

289 boundaries of the fishery, and this effect was most evident using the VMS data (Figure 4).

290 This resulted in grid cells covering areas that had not been identified as fishing grounds from

291 LK polygons (Figure 4, 5). The boundaries of the data also became increasingly abstract.

292 
293 Table 2: Estimate of the area of extent impacted by the king scallop fishery in the English Channel 294 using VMS data and LK data for the inshore and offshore scallop fleets, with data aggregated at 295 increasing grid cell sizes.

\begin{tabular}{cccc}
\hline Data & Grid cell size (decimal degrees) & Area $\left(\mathbf{k m}^{\mathbf{2}}\right)$ & $\begin{array}{c}\text { \% increase in area of } \\
\text { extent } \boldsymbol{c} . f . \mathbf{0 . 0 2 5} \text { degree } \\
\text { cells }\end{array}$ \\
\hline \multirow{2}{*}{ VMS } & 0.025 decimal degree cells & 44,821 & \\
& 0.1 raster & 83,326 & $86 \%$ \\
\hline \multirow{2}{*}{ LK offshore } & 0.3 raster & 124,300 & $177 \%$ \\
& raw polygons & 81,636 & $8 \%$ \\
\hline \multirow{2}{*}{ LK inshore } & 0.1 raster & 88,024 & $35 \%$ \\
& 0.3 raster & 110,489 & $19 \%$ \\
& raw polygons & 33,586 & $16 \%$ \\
\hline
\end{tabular}



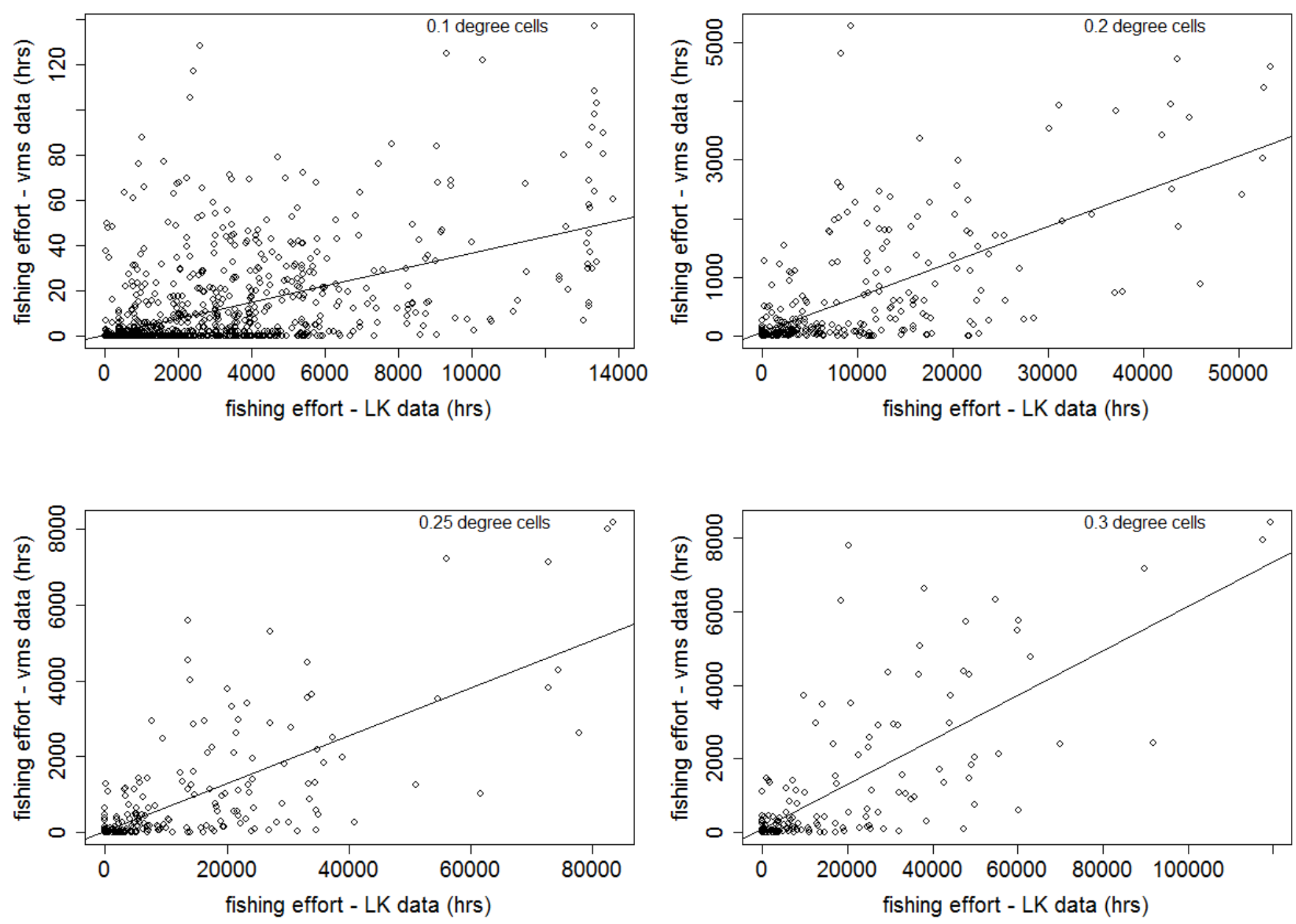

Figure 3: Plots of king scallop dredge fishing effort values derived from VMS data (2006-2013; >15m LOA vessels, total fleet) and fisher polygons (LK data; >15m LOA vessels, c. 50 \% fleet sample) (2002-2013). Data points extracted at four different spatial scales: $0.1 ; 0.2 ; 0.25 ; 0.3$ decimal degrees. Significant modelled linear regression lines are displayed. The $r^{2}$ and $p$ values are given in table 3 . 
301 Table 3: Results of linear regressions for fishing effort data calculated from VMS data and fisher 302 polygons (LK data) extracted at different cell sizes, d.f. $=$ degrees of freedom.

\begin{tabular}{cccccc}
\hline $\begin{array}{c}\text { Grid cell size } \\
\text { decimal degrees) }\end{array}$ & cell dimensions & cell area & $\boldsymbol{R}^{2}$ value & d.f. & $\boldsymbol{p}$ value \\
\hline 0.1 & $7.2 \times 11.1$ & $80 \mathrm{~km}^{2}$ & 0.28 & 1,1083 & $<0.001$ \\
0.2 & $14.4 \times 22.2$ & $320 \mathrm{~km}^{2}$ & 0.45 & 1,332 & $<0.001$ \\
0.25 & $18.0 \times 27.8$ & $500 \mathrm{~km}^{2}$ & 0.51 & 1,231 & $<0.001$ \\
0.3 & $21.0 \times 33.0$ & $693 \mathrm{~km}^{2}$ & 0.53 & 1,175 & $<0.001$ \\
\hline
\end{tabular}

303

304

305

306

307

308

309

310

311

312

313 


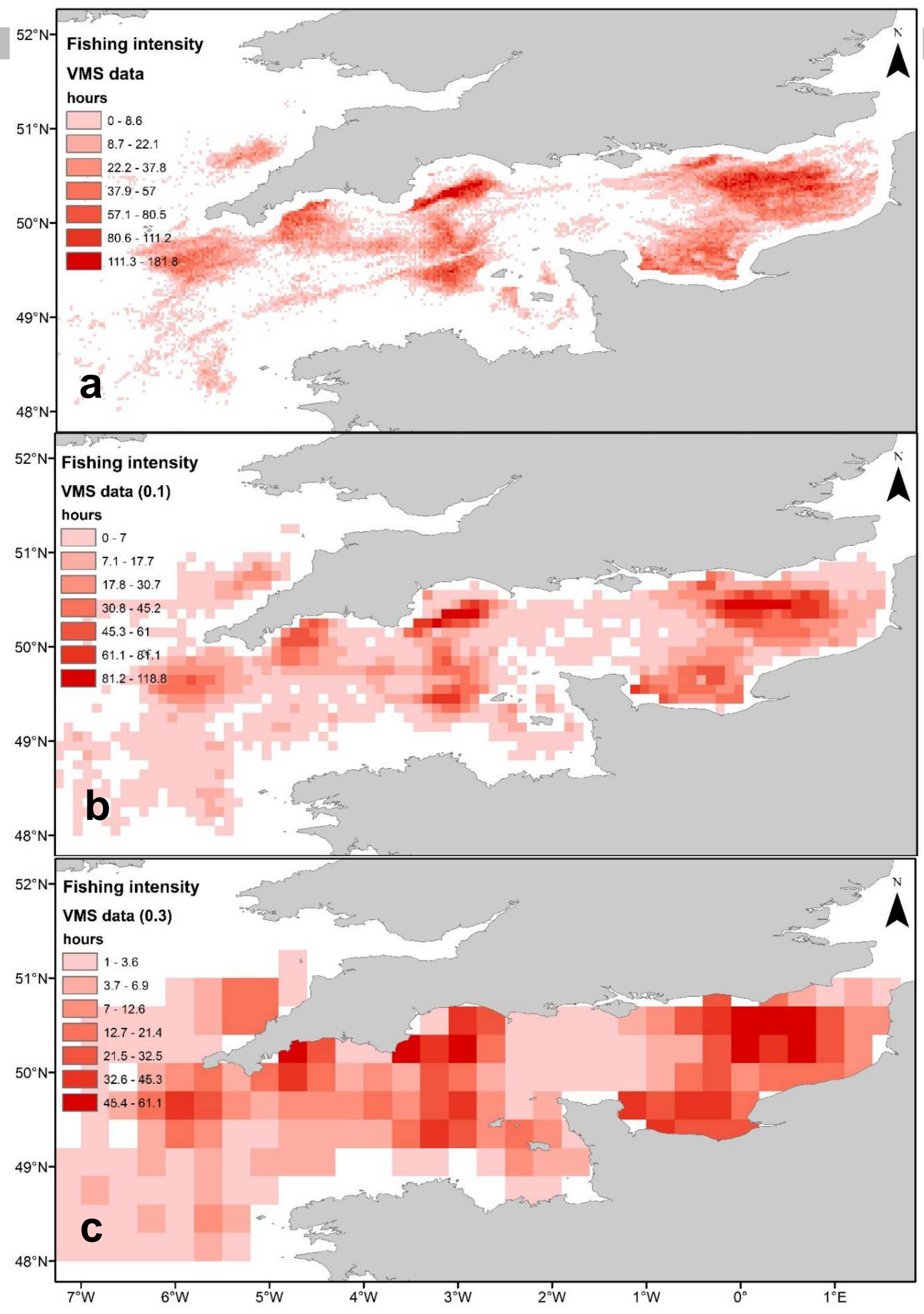

Figure 4: King scallop fishing intensity for all UK and foreign scallop vessels $>15 \mathrm{~m}$ LOA in the English Channel, expressed as the total number of hours fishing activity for the reference period 2006 to 2013, derived from VMS data for all UK and foreign vessels, aggregated at: a) 0.025 decimal degree grid cells; b) 0.1 decimal degree grid cells; c) 0.3 decimal degree grid cells. Darker shading indicates higher values of fishing intensity. Note the different scale applied to each figure. 


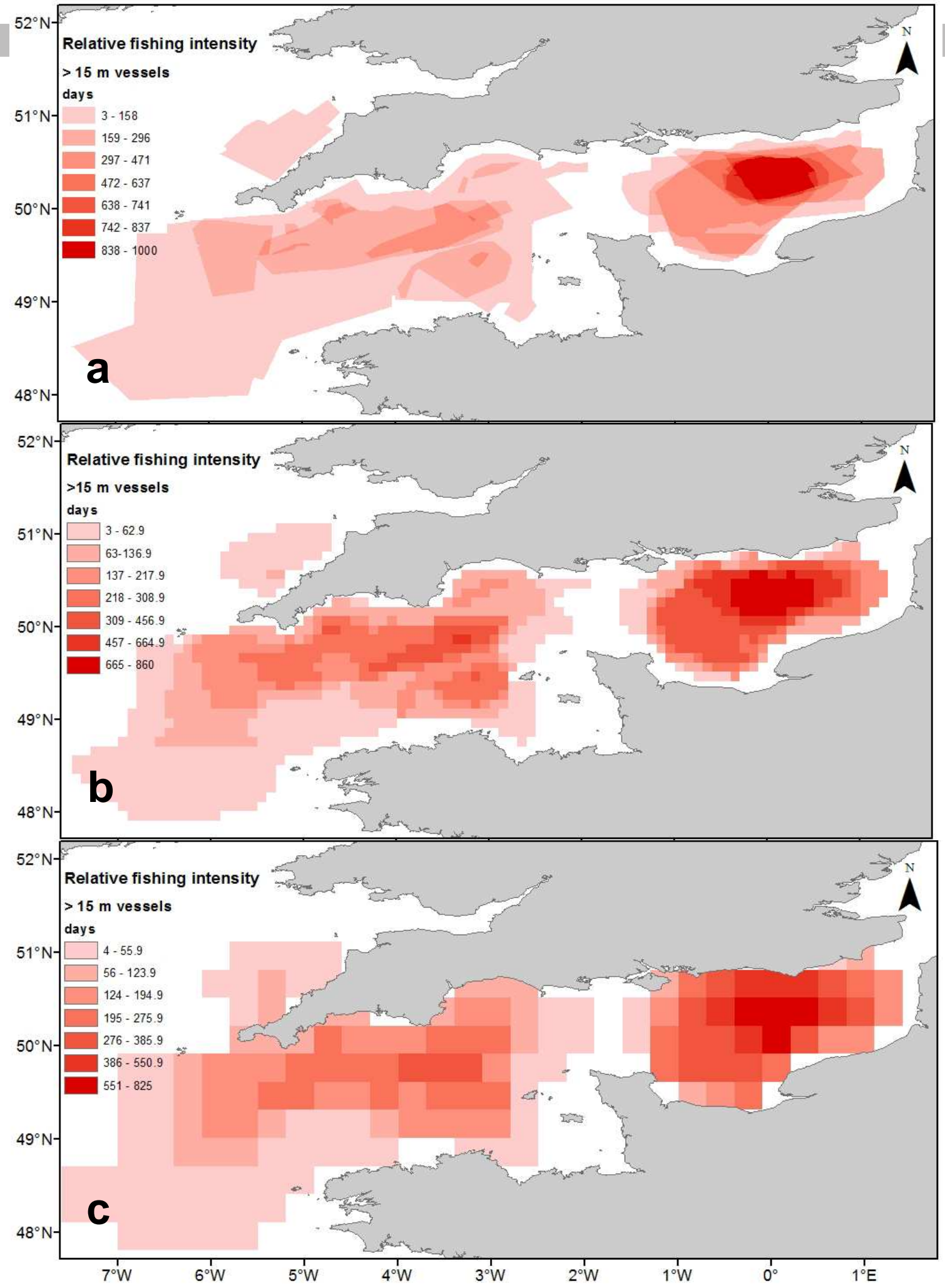

Figure 5: LK data for $>15 \mathrm{~m}$ LOA scallop vessels in the English Channel, covering the period 2002-2013, displayed as: a) raw data (polygons); b) data aggregated at $0.1^{\circ}$ grid cells; c) data aggregated at $0.3^{\circ}$ grid cells. Although data values (days fished per year, weighted over a 10 year reference period) are actual values gathered during the study, these are qualitative and are intended to represent the relative number of vessel days ( 24 hour operations) fishing over a 10 year reference period, from a $c .50 \%$ fleet sample. Darker shading indicates higher values of fishing intensity. Note the different scale applied to each figure. 


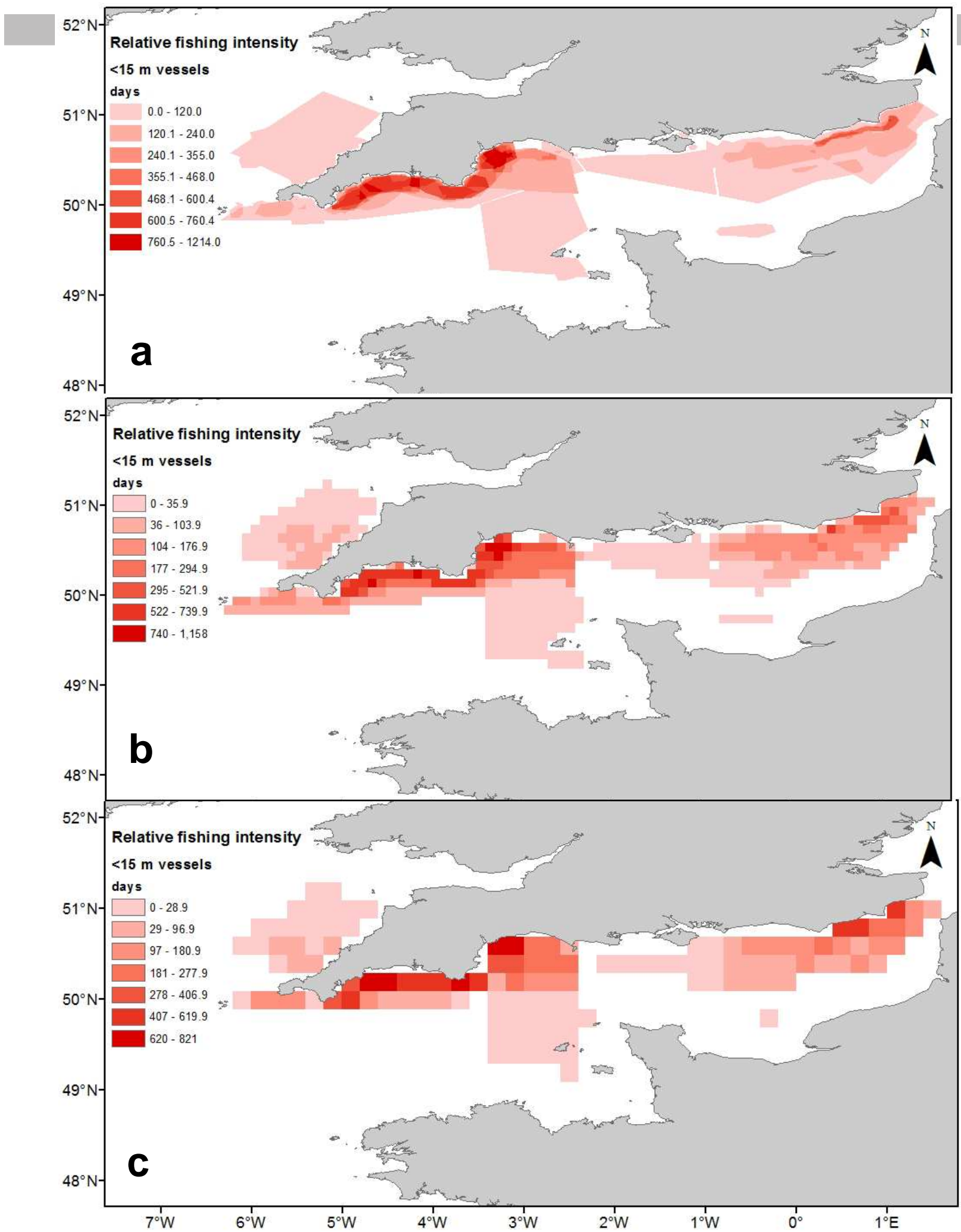

Figure 6: LK data for $\leq 15 \mathrm{~m} \mathrm{LOA}$ scallop vessels in the English Channel, covering the period 2002-2013, displayed as: a) raw data (polygons); b) data aggregated at $0.1^{\circ}$ grid cells; c) data aggregated at $0.2^{\circ}$ grid cells. Although data values (days fished per year, weighted over a 10 year reference period) are actual values gathered during the study, these are qualitative and are intended to represent the relative number of vessel days fishing over a 10 year reference period, from a $c .25 \%$ fleet sample. For vessels $\leq 15 \mathrm{~m}$ in length, total fishing time in a day varies from 8-24 hours. Darker shading indicates higher values of fishing intensity. Note the different scale applied to each figure. 


\section{Discussion}

Where electronic vessel tracking data and spatially resolved effort data for fleet activity are non-existent or not available for use, semi-structured interviews create open dialogue and offer opportunities for scientists and policy-makers to better understand socio-economic drivers of fishers' activities and inform long-term solutions to issues in fisheries management (Yates et al., 2014). The reliability and accuracy of local knowledge (LK) varies with context and species (Gilchrist et al., 2005; O’Donnell et al., 2012). However, for a species such as the

414 king scallop that has a consistent association with seabed habitat, the reliability of LK data can be high (Shepperson et al., 2014). In the present study, older fishers had fishing experience that spanned decades and were able to impart specific knowledge of the state of scallop stocks (relative to the past) for areas in which they had fished for many years; although shifting perceptions of baseline must be considered with such information (Pauly, 1995).

\section{Validation of LK data with VMS data}

Local knowledge derived from just over half $(54 \%)$ of the offshore fleet that operated in the fishery gave a good visual representation of the maximum spatial extent of fishing activity when compared to $100 \%$ VMS coverage. However, the estimate of the total area of extent of seabed impacted was inflated, due to the coarse resolution of the LK polygons. LK data is limited by the precision at which individual fishers report fishing grounds and the overall accuracy is affected by sample size, and analysis grid resolution (Shepperson et al., 2014). In relation to both the VMS and LK data, as the grid cell size used for aggregation increases, the border of the area of impact becomes increasingly abstract. This can be critical if overlaps between fisheries activities and conservation features (such as Marine Conservation Zones) need to be identified. Thus, the smallest feasible grid cell size may be useful when delineating fishing grounds. Using larger grid cells reduces the inherent variability in the data and mitigates against individual error in reporting. However, the extent of the area impacted by the fishery can be over-estimated, which may lead to inflated estimates of environmental impact (Shepperson et al., 2014).

When data were aggregated into grid cells of 0.3 decimal degrees (the largest grid cell used) 
comparison to the raw polygon data. If we assume the LK data to be a valid measure of

438 fishing extent (discussed further on), this suggests that smaller grid cells (e.g. $<0.1$ decimal

439 degrees) may provide more accurate maps of the area of impact. This is important to consider

440 if such information is used in spatial management. For the inshore fleet, the estimate of area

441 of extent impacted increased by $16 \%$ when the data were aggregated using grid cells of 0.2

442 decimal degrees compared to the raw data. However, the increase was slightly greater (19\%)

443 when aggregating at smaller ( 0.1 degree) grid cells, due to the data processing methods of the

444 GIS software in formation of raster layers. Hence, there is a necessary trade-off when

445 evaluating spatial patterns of fishing intensity, and the appropriate scale should be chosen

446 depending on the intended use of the data.

447 When considering the distribution of fishing effort, there were significant correlations 448 between the LK and VMS data (relating to vessels $>15 \mathrm{~m} \mathrm{LOA}$ ). Correlation of LK with VMS 449 data increased with increasing cell size, with moderate, significant correlations $(0.45 ; 0.51$; $450 \quad 0.53$ ) at grid cell sizes of $0.2,0.25$ and 0.3 decimal degrees, respectively. Using a larger grid 451 cell size when assessing fishing intensity will buffer against inaccuracies in the data 452 (Shepperson et al., 2014). It is therefore suggested that a grid cell of between 0.1-0.2 decimal 453 degrees $\left(c .80-320 \mathrm{~km}^{2}\right)$ provides the best trade-off between inaccuracies in LK data and the 454 overestimation of total area for the offshore scallop fishery in the English Channel when 455 compared to VMS data. A limitation of VMS data are the assignment of 'Unknown' gear 456 type to a substantial proportion of records. For the full VMS dataset obtained for use in the 457 present study, c. $70 \%$ of records were classified as 'Dredge' gear, and c. $30 \%$ as 458 'Unknown', thereby requiring an assumption of gear type and a decision on whether to 459 include or exclude a large proportion of data (Szostek, 2015). The time interval between 460 successive VMS transmissions can also be very variable. Both the latter issues hinder the 461 accuracy of the analysis. However, VMS data still represent the most reliable and 462 comprehensive source of fishing effort data for vessels $>15 \mathrm{~m}$ LOA, but can be enhanced when combined with other sources of fishing effort data (Russo et al., 2016). In the study by 464 Shepperson et al. (2014), grid cells of $25 \mathrm{~km}^{2}$ were the largest used in analysis of scallop 465 fishing activity around the Isle of Man (Irish Sea) and gave the highest agreement between 466 LK and VMS data. In the present study, the smallest grid cells used were substantially larger 467 (approximately $80 \mathrm{~km}^{2}$ ), therefore we consider that the scale of analysis of LK data will yield 468 reasonable accuracy for the English Channel scallop fishery. 
Shepperson et al. (2014) also found that a larger sample size of the fleet increased the

470

471

472

473

474

475

476

477

478

479

480

481

482

483

484

485

486

487

488

489

490

491

492

493

494

495

496

497

498

499

500 accuracy of estimated fishing intensity. A subsequent reduction in sample size from $100 \%$ of the fleet to $33 \%$ led to a $9 \%$ reduction in the Kappa agreement statistic, which accounts for the likelihood of chance agreement between datasets (Cohen, 1968). In the study by Shepperson et al., the resultant Kappa value based on a $33 \%$ sample of all scallop fishing vessels was 0.57 , using a $25 \mathrm{~km}^{2}$ grid cell, This value falls just below the threshold Kappa value of 0.6 that is considered to indicate 'substantial agreement' between data sources (Landis \& Koch, 1977). Although the Kappa statistic could not be assigned in the present study due to the different units used in analysis of VMS and LK data, for the offshore fleet in the present study, of which $54 \%$ were sampled, the largest grid cell $\left(693 \mathrm{~km}^{2}\right)$ is considered to provide a reasonably accurate estimation of the distribution of fishing effort.

\section{Assessing confidence in $L K$ data}

Although it was not possible to validate the inshore LK data with VMS data, the significant correlations found between the offshore LK and VMS data increase our confidence in the LK dataset as a whole. Visual assessment of the aggregated LK data by fishers that had taken part in the original questionnaire, also confirmed that they were a good representation of real effort distribution. Therefore, we are confident that the maps of inshore scallop fishing activity produced using LK data are an accurate representation of reality. The detailed maps of inshore fishing activity across the entire UK coast of the English Channel we present (Figure 6) are the first of their kind and can be used to highlight areas of economic importance, particularly in the consideration of marine spatial planning.

Individuals demarcated fished areas with varying levels of precision; inshore fishermen frequently drew small polygons in specific locations, whereas offshore skippers tended to map their activity with few polygons, covering a larger area. In the western English Channel, offshore fishing activity is sparse (indicated by discrete patches of low intensity VMS data). However, offshore skippers drew polygons that covered large areas of the western English Channel to reflect the maximum range that they had travelled to fish in the previous 10 years. Hence, the LK data failed to represent the fine scale detail in fishing activity that can be revealed by VMS data and led to an overestimation of the total seabed area impacted by the offshore fleet. It also resulted in many zero hour VMS records lying within low intensity LK polygons, thereby reducing the overall correlation between the two datasets. Thus, it appears that using LK to represent the extent of the offshore fishery is a precautionary method in 
501

502

503

504

505

506

507

508

509

510

511

512

513

514

515

516

517

518

519

520

521

522

523

524

525

526

527

528

529

530

531

terms of describing potential impact. There was greater visible correlation between the VMS and LK data in areas of concentrated fishing intensity; therefore the LK is likely to be more accurate where fishing activity occurs most frequently.

It was not possible within the scope of the study to interview skippers at every single port, however interviews were conducted at a range of landing ports along the coast to ensure the inshore activity recorded was representative across the full spatial extent of the fishery. Although skippers may have different home ports, fishing grounds indicated by skippers from nearby ports frequently overlapped, indicating that many skippers visited the same traditional fishing grounds. For example, although no inshore skippers from Southampton were interviewed, fishing grounds to the east of the Isle of Wight were identified by a Welsh skipper that had fished in that area. The scallop fishery in this area is limited; a byelaw in the Southern IFCA district restricts vessels to $12 \mathrm{~m}$ LOA or less, towing 3 or 4 dredges in total and there were only 5 or 6 vessels landing scallops into Southampton at the time of this study (Neil Richardson, Southern IFCA, pers. comm.). An increased sample size would increase the accuracy of estimates of relative fishing intensity but is unlikely to significantly alter the predicted spatial extent of inshore fishing activity.

In the process of aggregating data from all interviewees, 'hotspots' of scallop fishing activity were highlighted by the inshore LK map, reflecting traditional fishing grounds along the coast. There is less inshore scallop activity in the eastern English Channel; however the highest levels of activity are concentrated close to the Sussex shoreline (Vanstaen et al., 2010; Vanstaen \& Silva, 2010). Areas of lower activity for the inshore fleet tend to be in locations that are further from shore or landing ports, or are only visited during extended periods of good weather, such as the Channel Islands (as smaller vessels are more vulnerable at exposed locations such as these).

The precise location of inshore fishing activity is pertinent when considering the designation of Marine Conservation Zones (MCZs), which contribute to the UK's network of marine protected areas to meet commitments under the Convention on Biological Diversity, and achieve 'Good Environmental Status' under the EU Marine Strategy Framework Directive (JNCC \& Defra, 2012). Such areas have been implemented to conserve sensitive seabed features and habitats but can also lead to cultural, social and economic impacts (Whitmarsh et al., 2002). 
533 Many factors can influence patterns of fishing activity and fleet dynamics (Putten et al., 534 2012). There has been a reduction in the spatial footprint of the offshore scallop fleet in 535 recent years, observed in the raw data in the present study and by Campbell et al. (2014). 536 This is due in part to a restriction on annual fishing effort (measured as $\mathrm{kW}$ days) for the $>15$ $537 \mathrm{~m}$ fleet in ICES area VII. Of those interviewed, $85 \%$ of offshore skippers fished in both areas 538 VIId and VIIe. This is in contrast to inshore skippers, of whom the majority fished in either 539 area VIId, or VIIe exclusively (depending on the location of their home port), while just $24 \%$ 540 fished in both areas. This confirms the anecdotal observation that $>15 \mathrm{~m} \mathrm{LOA}$ vessels tend to 541 be nomadic while $\leq 15 \mathrm{~m}$ vessels are more locally restricted in areas where they fish (pers. 542 comm. Jim Portus, CEO, Southwest Fish Producers Organisation).

543 Legislation such as area closures and effort restrictions inhibit activity of both the inshore and 544 offshore fleets. Ground closures displace the impacts of fishing to other locations 545 (Greenstreet et al., 2009), with financial and socio-economic impacts on fishers. Skippers of 546 inshore vessels reported that in recent years their fishing had been impacted by area closures 547 including the special area of conservation (SAC) in Lyme Bay, Marine Conservation Zones 548 (MCZs) in Falmouth Bay (Reker, 2015) and recent closures around the Isle of Wight, Start 549 Bay, Torbay, Falmouth, the Scilly Isles (all in the English Channel) and Cardigan Bay and 550 Caernarfon Bay (in Welsh waters) as a result of habitat conservation measures. Due to these 551 closures, $28 \%$ of inshore fishers reported having to travel further from their home port to 552 fish, while $72 \%$ travelled the same distance to fish as 10 years ago. This has resulted in more 553 time spent at sea, increased fuel expenditure and greater vulnerability to weather conditions 554 (closures generally occur in areas close to shore that are less exposed to extreme weather 555 conditions).

556 Therefore, when proposing sites to meet conservation objectives, careful consideration should 557 be made of potential impacts on fleet behaviour. Currently, the total area of MCZs 558 (designated under the Marine and Coastal Access Act 2009 (Hill et al., 2010)) and Special 559 Areas of Conservation (SACs) in the UK is $20,425 \mathrm{~km}^{2}$, of which $3145 \mathrm{~km}^{2}$ is in the English 560 Channel (data from http://jncc.defra.gov.uk/) (Figure 7). Thus, 9\% of the inshore scallop 561 fishing grounds (calculated from LK data), and 7\% of the offshore scallop fishing grounds, 562 could potentially be affected by MCZ management measures (Figure 7). 


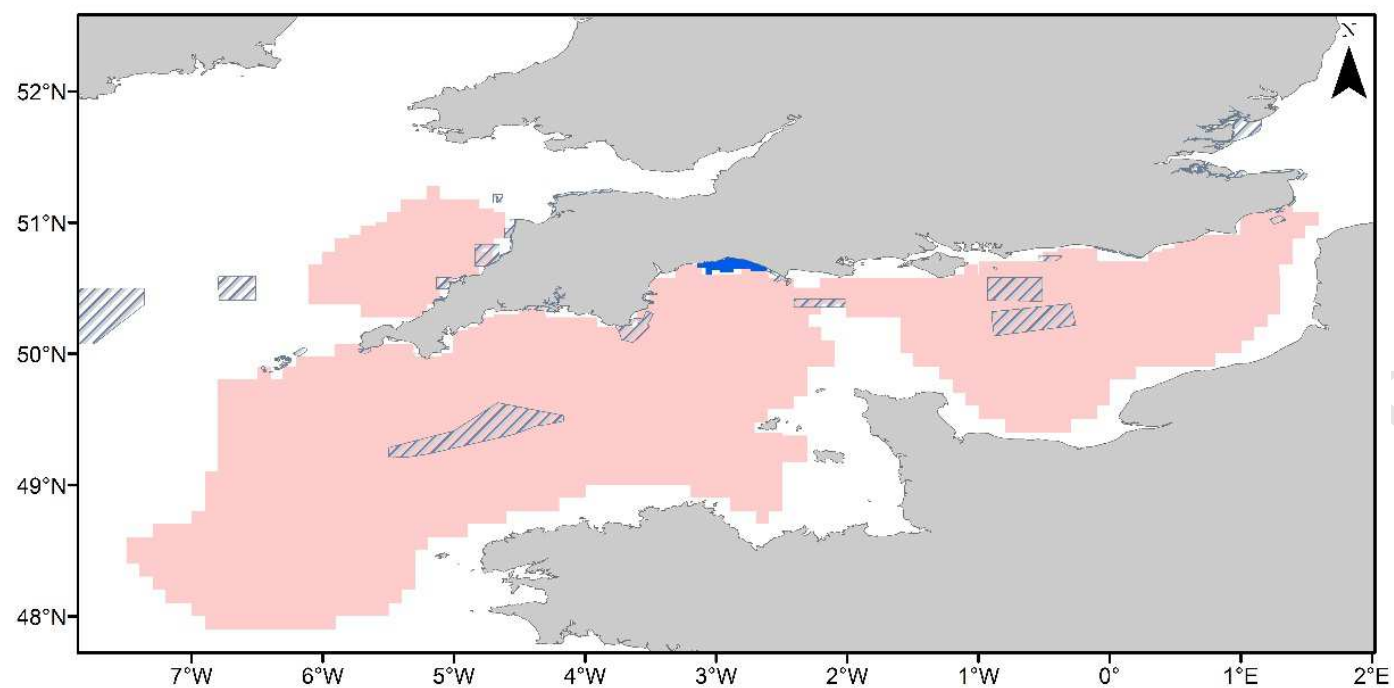

Figure 7: Location of designated Marine Conservations Zones (MCZs) in the English Channel and north of Cornwall (shown with hatching). The Lyme Bay Special Area of Conservation (SAC) is indicated in blue. Data from http://jncc.defra.gov.uk/. Scallop dredging grounds identified from LK data are shown in pink.

\section{8}

\section{Conclusions}

570 The extent to which LK data reflect empirical measures of fishing effort can vary with

571 fishery, fleet sector, sample size, and scale of aggregation. Therefore it is important to assess

572 each metier individually. In the present study we have demonstrated an example, in a high-

573 value shellfish fishery, of where LK can be used to reliably inform development of fishing

574 effort data for the purposes of management. A suite of environmental and socio-economic

575 factors influence king scallop fishing activity. The inshore king scallop fleet fish on

576 traditional grounds in the English Channel and is impacted considerably by ground closures,

577 including existing MCZs and SACs. In comparison to this, the offshore fleet has access to

578 large areas of productive fishing ground, but economic drivers have reduced the spatial extent

579 of activity in recent years.

580 The LK data in the present study have certain limitations; <100\% fleet coverage and a trade-

581 off between scale and accuracy. However, LK data provide a tangible alternative in data

582 deficient situations and have been demonstrated to be accurate for other king scallop fisheries

583 (Shepperson et al., 2014). However, for management decisions that require more precise

584 estimates of fishing effort, sampling the entire fleet is desirable (Shepperson et al., 2014).

585 Insight gained from fishers could be incorporated into the development of future management

586 plans for an economically and environmentally sustainable fishery. The present study 
587 represents a useful resource for fisheries managers, in defining the spatial and temporal

588 utilisation of fishing grounds frequented by the scallop dredge fleet across the English

589 Channel. The data can be overlaid with habitat and stock information to help evaluate 590 potential benefits and conflicts of alternative management options. 


\section{Acknowledgements}

592 The authors would like to thank all the fishermen and vessel owners who contributed their 593 time and knowledge to this study. The research was funded by members of the UK Scallop 594 Association, Morrisons and the Fishmongers Company, in collaboration with CEFAS.

595

596 References

597 Bergmann, M., Hinz, H., Blyth, R.E., Kaiser, M.J, Rogers, S.I, Armstrong, M. (2004). Using 598 knowledge from fishers and fisheries scientists to identify possible groundfish "Essential 599 Fish Habitats', Fisheries Research 66: 373-379. http://dx.doi.org/10.1016/ 600 j.fishres.2003.07.007

601 Breen, P., Vanstaen, K., Clark, E.W.E. (2014). Mapping inshore fishing activity using aerial, 602 land and vessel-based sighting information. ICES Journal of Marine Science: 603 doi:10.1093/icesjms/fsu115

604 Campbell, M.S., Stehfest, K.M., Votier, S.C., Hall-Spencer, J.M. (2014). Mapping fisheries 605 for marine spatial planning: Gear specific vessel monitoring system (VMS), marine 606 conservation and offshore renewable energy. Marine Policy 45: 293-300.

607 Clarke, K.R. \& Gorley, R.N., 2006. PRIMER v6: User Manual/Tutorial. PRIMER-E, 608 Plymouth.

609 Clarke, K. R., and Warwick, R. M. (2001). Change in Marine Communities: an Approach to 610 Statistical Analysis and Interpretation, 2nd edn. PRIMER-E, Plymouth.

611 Close, C.H. \& Hall, B. G. (2006). A GIS-based protocol for the collection and use of local 612 knowledge in fisheries management planning. Journal of Environmental Management 78: $613 \quad 341-352$.

614 Cohen, J. (1968). "Weighed kappa: Nominal scale agreement with provision for scaled 615 disagreement or partial credit". Psychological Bulletin 70 (4): 213-220.

616 Council of the European Union (1992). Council Directive 92/43/EEC of 21 May 1992 on the 617 conservation of natural habitats and of wild fauna and flora. 
618 Council of the European Union (2008). Council Directive 2008/56/EC of the European

619 Parliament and of the Council of 17 June 2008 establishing a framework for community

620 action in the field of marine environmental policy (Marine Strategy Framework Directive).

621 des Clers, S., Lewin, S., Edwards, D., Searle, S., Lieberknecht, L. and Murphy, D. (2008).

622 FisherMap. Mapping the Grounds: recording fishermen's use of the seas. Final Report. A 623 report published for the Finding Sanctuary project.

624 Drew, J., (2005). Use of traditional ecological knowledge in marine conservation. 625 Conservation Biology 19: 1286-1293. http://dx.doi.org/10.1111/j.1523-1739.2005. 00158.

626 Dunn D.C., Stewart, K., Bjorkland, R.H., Haughton, M., Singh-Renton, S., Lewison, R., 627 Thore, L., Halpin, P.N. (2010). A regional analysis of coastal and domestic fishing effort in 628 the wider Caribbean. Fisheries Research 102: 60-68.

629 Gerritsen, H. D., Minto, C., and Lordan, C. (2013). How much of the seabed is impacted by 630 mobile fishing gear? Absolute estimates from Vessel Monitoring System (VMS) point data. 631 ICES Journal of Marine Science, doi.10.1093/icesjms/fst017.

632 Gilchrist, G., Mallory, M., Merkel, F (2005). Can local ecological knowledge contribute to 633 wildlife management? Case studies of migratory birds. Ecology and Society 10(1):20.

634 Greenstreet, S.P.R., Fraser, H.M., Piet, G.J. (2009). Using MPAs to address regional-scale 635 ecological objectives in the North Sea: modelling the effects of fishing effort displacement. 636 ICES Journal of Marine Science 66: 90-100.

637 Hall, G. B. \& Close, C.H. (2007). Local knowledge assessment for a small-scale fishery 638 using geographic information systems. Fisheries Research 83: 11-22.

639 Hill, J., Pearce, B., Georgiou, L., Pinnion, J., Gallyot, J. (2010). Meeting the MPA Network 640 Principle of Viability: Feature specific recommendations for species and habitats of 641 conservation importance. Natural England Commissioned Reports, Number 043. 189p.

642 Hintzen, N. T., Piet, G. J., and Brunel, T. (2010). Improved estimation of trawling tracks 643 using cubic Hermite spline interpolation of position registration data. Fisheries Research 101: 644 108-115.

645 Howarth, L. M. \& Stewart, B. D. (2014). The dredge fishery for scallops in the United 646 Kingdom (UK): effects on marine ecosystems and proposals for future management. Report 
to the Sustainable Inshore Fisheries Trust. Marine Ecosystem Management Report no. 5,

648 University of York, $54 \mathrm{pp}$.

649 Jenks, G.F. (1967). "The Data Model Concept in Statistical Mapping", International 650 Yearbook of Cartography 7: 186-190.

651 Jennings, S. \& Lee, J. (2012). Defining fishing grounds with vessel monitoring system data. 652 ICES Journal of Marine Science 69: 51-63.

JNCC \& Defra (on behalf of the Four Countries' Biodiversity Group) (2012). UK Post-2010

654 Biodiversity Framework. July 2012. Available from: http://jncc.defra.gov.uk/page-6189.

Kafas, A. McLay, A., Chimienti, M. \& Gubbins, M. (2014). ScotMap Inshore Fisheries

Kaiser M.J., Clarke, K.R., Hinz, H., Austen, M.C.V., Somerfield, P.J., Karakassis, I. (2006).

661 Lambert, G. I., Hiddink, J. G., Hintzen, N. T., Hinz, H., Kaiser, M. J., Murray, L. G., and 662 Jennings, S. (2012). Implications of using alternative methods of vessel monitoring system 663 (VMS) data analysis to describe fishing activities and impacts. ICES Journal of Marine 664 Science 69: 682-693.

665 Landis, J.R., Koch, G.G. (1977). The measurement of observer agreement for categorical 666 data. Biometrics 33 (1): 159-174.

667 Lee, J., South, A. B., and Jennings, S. (2010). Developing reliable, repeatable and accessible 668 methods to provide high-resolution estimates of fishing-effort distributions from Vessel Monitoring System (VMS) data. ICES Journal of Marine Science 67: 1260-1271.

670 Leite, M.C.F., Gasalla, M.A., 2013. A method for assessing fishers' ecological knowledge as a practical tool for ecosystem-based fisheries management: seeking consensus in south eastern Brazil. Fisheries Research 145: 43-53.

673 Lieberknecht, L. M., Hooper, T. E. J., Mullier, T. M., Murphy, A., Neilly, M., Carr, H., 674 Haines, R., Lewin, S., and Hughes, E. (2011). Finding Sanctuary final report and 
675 recommendations. A report submitted by the Finding Sanctuary stakeholder project to Defra, 676 the Joint Nature Conservation Committee, and Natural England.

677 Likert, R. (1932). A Technique for the Measurement of Attitudes. Archives of 678 Psychology 140: 1-55.

679 Mills, C.M., Townsend, S.E., Jennings, S., Eastwood, P.D., Houghton, C.A. (2007). 680 Estimating high resolution trawl fishing effort from satellite-based vessel monitoring system 681 data. ICES Journal of Marine Science 64 (2): 248-255.

682 MMO (2012). UK Sea Fisheries Annual Statistics 2012. Marine Management Organisation, 683 London. pp. 98.

684 O’Donnell, K.P., Molloy, P.P., Vincent, A.C., 2012. Comparing fisher interviews, logbooks, 685 and catch landings estimates of extraction rates in a small-scale fishery. Coastal Management 686 40: 594-611.

687 Palmer, D. (2006). The Scallop fishery in England and Wales. Meeting of the North Western 688 Waters Regional Advisory Committee, London, UK.

689 Pauly, D. (1995). Anecdotes and the shifting baseline syndrome of fisheries. Trends in 690 Ecology and Evolution 10: 430.

691 Pederson, S. A., Fock, H.O., Sell, A.F. (2009). Mapping fisheries in the German exclusive 692 economic zone with special reference to offshore Natura 2000 sites. Marine Policy 33: 571693590.

694 Piet, G.J. and Quirijns F.J. (2009). The importance of scale for fishing impact Estimations. 695 Canadian Journal of Fisheries and Aquatic Science 66: 829-835.

696 Putten, I.E., Kulmala, S., Thebaud, O., Dowling, N., Hamon, K.G., Hutton, T., Pascoe, S. 697 (2012). Theories and behaviours underlying fleet dynamics models. Fish and Fisheries 13: $698 \quad 216-235$.

699 R Development Core Team (2008). R: A language and environment for statistical computing. 700 R Foundation for Statistical Computing, Vienna, Austria. ISBN3-900051_07_0, URL 701 http://www.R-project.org. 
Reker, J. (2015). Marine protected areas in Europe's seas. An overview and perspectives for

703

704

705

706

707

708

709

710

711

712

713

714

715

716

717

718

719

720

721

722

723

724 Vanstaen, K., Clark, R., Ware, S., Eggleton, J., James, J.C.W., Cotteril, C., Rance, J. Manco,

725 F. and Woolmer, A. (2010). Assessment of the distribution and intensity of fishing activities 726 the future. European Environment Agency report no.3/2015. European Environment Agency, Luxembourg, pp. 38.

Rochet, M-J., Prigent, M., Bertrand, J. A., Carpentier, A., Coppin, F., Delpech, J-P., Fontenelle, G., Foucher, E., Mahe', K., Rostiaux, E., and Trenkel, V. M. (2008). Ecosystem trends: evidence for agreement between fishers' perceptions and scientific information. ICES Journal of Marine Science 65: 1057-1068.

Russo, T., D’Andrea, L., Parisi, A., Martinelli, M., Belardinelli, A., Boccoli, F., Cignini, I., Tordoni, M., Cataudella, S. (2016). Ecological Indicators 69: 818-827.

Sciberras, M., Hinz, H., Bennell., J.D., Jenkins, S.R. (2013). Benthic community response to scallop dredging closure within a dynamic seabed habitat. Marine Ecology Progress Series 480: 83-98.

Shepperson, J., Murray, L.G., Cook, S., Whitley, H., Kaiser, M.J. (2014). Methodological considerations when using local knowledge to infer spatial patterns of resource exploitation in an Irish Sea fishery. Biological Conservation 180: 214-223.

Szostek, C.L. (2015). Chapter 3: Scaling of aggregated vessel monitoring system data for impact assessment of scallop dredging, In: Population characteristics and environmental interactions of the king scallop fishery in the English Channel. $\mathrm{PhD}$ thesis, Bangor University, pp. 296.

Turner, R.A., Polunin, N.V.C., Stead, S.M. (2015). Mapping inshore fisheries: Comparing observed and perceived distributions of pot fishing activity in Northumberland. Marine Policy 51: 173-181. in the vicinity of aggregate extraction sites. MALSF-MEPF Project 08/P73. Cefas, Lowestoft, $116 \mathrm{p}$.

Vanstaen, K. \& Silva, T. (2010). Integrated inshore and offshore fishing activities data layer in aggregate producing REC areas. MALSF-MEPF Project 09/P116. Cefas, Lowestoft, 97p. 
730 Whitmarsh, D., James, C., Pickering, H., Pipitone, C., Badalamenti, F., D’Anna, G. (2002).

731 Economic effects of fisheries exclusion zones: A Sicilian case study. Marine Resource 732 Economics Vol. 17, no. 3: 239-250.

733 Yates, K.L. \& Schoeman, D.D. (2013). Spatial Access Priority Mapping (SAPM) with 734 Fishers: A Quantitative GIS Method for Participatory Planning. PLoS ONE 8(7): e68424. 735 doi:10.1371/journal.pone.0068424. 


\section{English Channel Scallop Fishery Survey}

739 Thank you for participating in this questionnaire. The aim is to increase knowledge about the

740 English Channel scallop fishery and the information will be used to support the Scallop

741 Association and its members in the sustainable management of the fishery.

Do you have any questions before we begin........?

\section{Gear information}

1. Gear type used:

Newhaven / other (please specify)

2. Do you plan to increase or decrease engine size in next 12 months? $\mathbf{Y} / \mathbf{N}$ (please give details)

\section{What is the:}

- Gear width

- No. of dredges used

- Dredge tooth spacing

- Belly ring size.

- Tooth length

3. Have you increased or decreased engine size in the last 10 years? $\mathbf{Y} / \mathbf{N}$ (please give details)

4. Do you plan to increase or decrease no. of dredges used in next $\mathbf{1 2}$ months? (please specify)

7625 . Have you increased or decreased no. of dredges used in the last $\mathbf{1 0}$ years? (please specify) 
Please answer the following questions in relation to your fishing habits in 2011:

6. On average, how many hours a day did you fish? hours

7. Approximately how many days did you fish? days

8. What is your average tow time? mins

9. What is your average tow speed? knots

10. What was your average catch per day (bags)?

11. What was the average bag weight/size?

12. What was your average trip length (days)? days

\section{Location of fishing}

Fish Map software used to record areas fished and number of days per month, main bycatch landed no. of years fished, importance of grounds.

13. What are the three most important factors that influence where you decide to fish?

For example: Weather (e.g. strong winds), vessel's total catch in that area in previous year, Condition of scallops, Distance from port, Cost of fuel, Number of other fishing vessels present on grounds

i.

ii.

iii.

14. What wind strength prevents you from fishing?

15. How do you decide where you will fish? (Please tick all that apply):

- Skippers knowledge/experience.

- Sharing knowledge with other boats/fishermen.

- Prospecting for new grounds

- Other (please specify).

16. Approximately what percentage of your fishing each year is in the same areas as the previous year, and what percentage is in new / different (occasional) areas?

Same: .$\%$

New / different areas: ..$\%$ 
17. If you fish in different grounds to 'normal', what are the 3 main reasons for this (in order)?

$$
\text { i. }
$$

ii.

iii.

18. Do you spend time prospecting for new scallop beds? If yes, approximately how many days per year do you spend doing this?

\section{Yes / No Number of days per year.}

19. If there are grounds that you fish on a rotational basis e.g. once every 2 or 3 years, what are the reason(s) for this?

20. In the last 10 years have there been any area based legislative reasons (e.g. area closures) that have affected where or how you would normally fish?

- Location(s)

- Why/how affected?

21. In the last $\mathbf{1 0}$ years have there been any technical legislative reasons (e.g. gear/engine size/effort restrictions, curfews) that have affected where or how you would normally fish?

- Location(s)?

- Why/how

affected?

22. Thinking about the last 10 years, how far would you normally travel from your home port to fish? (please state a range e.g. 50-200nm) .$n m$ 
830

831

832

833

834

835

836

837

838

839

840

841

842

843

844

845

846

847

848

849

850

851

852

853

854

855

856

857

858

859

860

23. What is the maximum distance you are willing or able to travel to fish?. .$n m$

24. In the last $\mathbf{1 0}$ years have you needed to travel further than normal from your home port to fish?

No 0-12nm 12-50nm 50-100nm 100-200nm >200nm

When and why? (e.g. fuel cost / scallop abundance/ restrictions)

If yes, where did you

go?

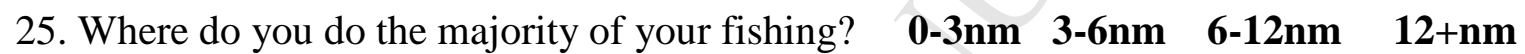

26. Has the way you fish for scallops changed in any other way over the last $\mathbf{1 0}$ years?

\section{Catch composition \& condition}

Please indicate on the paper map if you are aware which month(s) spawning occurs in a particular area and provide the following information if possible:

27. Does spawning occur at the same time of year in the area?

a) Yes it varies by less than a week

b) No, it can vary by 2 or 3 weeks

c) No, it can vary by a month or more

28. Do the majority of scallops in this area all spawn at approximately the same time or does it occur over a longer time period? 
861

862

863

864

865

866

867

868

869

870

871

872

873

874

875

876

877

878

879

880

881

882

883

884

885

886

887

888

889

890

891

a) Yes, most scallops spawn within a day or two of each other

b) Most scallops spawn within a week of each other

c) No, the spawning carries on for longer than a week

29. Are there any apparent triggers for spawning? (e.g. light, temp, sediment, water clarity, tides)

30. Does the timing of spawning influence where you decide to fish? (Please state how/why)

\section{Landings \& Profitability}

30. In the last $\mathbf{1 0}$ years has your overall catch increased or decreased?

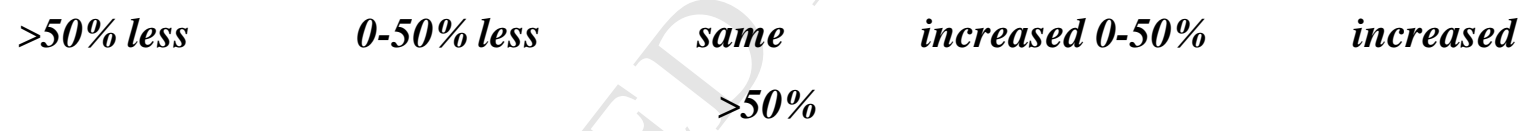

Please give possible reasons for this................................................

31. If possible please say which years were: particularly good (large catch): particularly poor (small catch):

32. In the last $\mathbf{1 0}$ years has your average catch weight per tow of MLS scallops increased or decreased?

$>50 \%$ less $\quad 0-50 \%$ less $\quad$ same $\quad$ increased $0-50 \% \quad$ increased $>50 \%$ Please give possible reasons for this 
892

893

894

895

896

897

898

899

900

901

902

903

904

905

906

907

908

909

910

911

912

913

914

915

916

917

918

919

920

921

922

923

33. What is your minimum commercially viable catch rate?

a. Bags per trawl

b. Bags per day.

By answering the following questions you will help place an economic value on the areas that you fish:

34. For your fishing activity in $\mathbf{2 0 1 1}$ please give an indication of:

- your annual gross landings (tonnes). . prefer not to answer

- the value of your annual landings (£) / prefer not to answer

- your annual profit $(\mathfrak{f})$ . prefer not to answer

35. Please estimate the percentage (\%) difference between 2011 and 2001:

- $\%$ change in your annual gross landings (tonnes). $\%$ increase / decrease

- \% change in the value of your annual landings $(£)$ $\%$ increase / decrease

- \% change in your annual profit (£) $\%$ increase / decrease

\section{Management}

36. Please answer these 3 statements questions using the following scale:
Strongly disagree
Disagree
Neither agree or disagree
Agree
Strongly agree

i. The fishery is currently fished at a sustainable level. Please give a reason for your answer......

ii. The fishery is at risk of being overfished. Please give a reason for your answer.

37. In your opinion, please indicate the three most effective ways of conserving scallop stocks for the future (i.e. fishing sustainably), in order of effectiveness (1-3): 
924

925

926

927

928

929

930

931

932

933

934

935

936

937

938

939

940

941

942

943

944

945

946

947

948

949

950

951
- Dredges per side limits.

- New dredge design.

- No. of teeth

- Belly ring size.........

- Vessel size limits

- Engine size limits

- Minimum landing size.......

- Permanent closed areas.......

- Seasonal closures.....

- Curfews

- TACs

- Restricted effort.

- Caps on licences

- Other (please specify)

38. Do you disagree with any of the current management measures in the English Channel?

39. Are there any other comments you would like to make? (Continue on separate sheet if necessary) 
Summary of vessel characteristics. Vessels are grouped by length $(\leq 15 \mathrm{~m} ;>15 \mathrm{~m} \mathrm{LOA})$. S.D. $=$ one standard deviation of the mean.






\section{Highlights}

- Local Knowledge (LK) from fishers can provide a reliable source of fishery spatial data

- LK data highlights important fishing grounds in the absence of empirical data sources

- A trade-off between accuracy and error reduction is required in analysis grid cell size 